\title{
Introducing the Asia Pacific Journal of Environment Ecology and Sustainable Development
}

\author{
ARR Menon ${ }^{1}$, Brijesh Sathian ${ }^{2}$ and VB Sreekumar ${ }^{1}$
}

${ }^{1}$ Scientist, Division of Ecology, Kerala Forest Research Institute, Peechi, Kerala, India.

${ }^{2}$ Assistant Professor, Department of Community Medicine, Manipal College of Medical Sciences, Pokhara, Nepal.

\section{Editorial}

\section{Corresponding Author:}

Dr. ARR Menon

Scientist,

Kerala Forest Research Institute,

Peechi, Thrissur- 680653

Kerala, India

E-mail: arrmenon@gmail.com

\section{Editorial}

Asia Pacific Journal of Environment Ecology and Sustainable Development has a broad aim to disseminate the environmental consciousness and sustainable development in the third world countries. Our main objective is to provide a platform for researchers who always possess a problem in publication for their research work due to financial constraints. Unfortunately majority of the journals including some of the Open Access Journals insists processing fee, publication charges etc. to authors for publishing their articles. The amount to be paid is much more to afford a researcher from the third world country and eventually it results the unpublished condition of a research work due to lack of money. So in the current scenario an unambiguous disparity exists between the researchers of poor countries including Nepal and Developed countries. In scientific parlance, scientific investigations must be fostered at global existing standards irrespective of fund. This uneven distribution of benefits due to cultural, linguistic and socio economic factors in the rich countries has adversely affected poor countries in the form of so called effect 'Brain Drain'. Research and development in Nepal should be intensified as well as openings to the researchers to be carved out in the major thrust areas.

Environmental health is essential for the maintenance of biological processes in the earth. Anthropogenic activities are diminishing our several ecological systems which results our planet unfit for survival of life. We are coming to realize that water deficits and water contamination would be the critical environmental issues in the future due to unprecedented population growth. Degradation of tropical forests, coral reefs, wetlands and other biologically rich landscapes is causing an alarming loss of species (William P. Cunningham and Mary Ann Cunningham, 2002). The word biodiversity first appeared in the biological abstracts "BIOSIS" data base 1988 with four reference and by the end of April, 1994 this had increased to 888 (Das and Choudhary, 2008). Biodiversity encompasses the variety of living things. It is the sum total of genes, species and ecosystems present in a region of the biosphere. It is estimated that the total number of species on this planet earth may close to 100 million, although the earlier estimates gave a figure of 10 to 30 million. From such a large number of species only about 1.4 million species of plants, animals and micro organisms have been given a scientific name. Biodiversity is responsible for the essential ecosystem services such as regulation of atmospheric gaseous composition, climate disturbance, formation of soil and maintenance of soil fertility, acquisition of nutrients, pollution control etc (Das and Choudhary, 2008). Tropical Rain Forests are the most ecologically fragile ecosystems in the world which are formed after millions of years of evolutionary processes. In biodiversity point of view they harbor more than half of the species on earth even though they represent seven percent of total land surface on earth. The rate of deforestation shows decreasing but it is alarmingly high that is about 13 million hectares of forests were converted to other uses in the last decade which is lesser compared to 16 million hectares lost per year during 1990's. Another area to be prioritized in conservation view point is that of mangroves which had shrunk to 15.6 million hectares from an earlier value of 16.1 million hectares (FAO, 2010).

Unfortunately several causative factors are leading to massive biodiversity depletion in various ecosystems in the World. Among the notable factors include 1) Habitat destruction, 2) Habitat fragmentation, 3) Habitat degradation, 4) Population pressure, 5) Over exploitation, 6) Introduction of exotic species etc. It is therefore critical to analyze empirical data as well as information's pertaining to environmental impacts for strengthening environmental management. 
So research relating to Environment as well as environmentally concerned citizens can influence government policies. In addition the researchers are required to render tacit environmental knowledge to explicit knowledge. Integration of traditional and indigenous knowledge has to be effectively used in conservation of biodiversity. Biodiversity can only be conserved if and when the better livelihoods for the poor people are ensured; as a result their dependency to the natural resources for livelihood is therefore reduced. There is a need to develop mechanisms to speedy redressal of environmental disasters, man-wildlife conflicts, interventions or issues between Government and vulnerable communities like ethnic groups. Women participation is essential for environmental protection and sustainable development for these purpose eco-development schemes, self help groups' etc. has to be intensified so that women empowerment as well as reduced dependence on natural resources can put in to practice. Environmental awareness and literacy are important for sustainable management of our natural resources.

Asia Pacific regions have been recognized as the potential sites for rapid developmental activities and there by resultant environmental destruction in large scale. We recommend the experts in this field to join as editors and reviewers in order to formulate or improve journals policy and researchers to make utilize this as a platform to put out major environmental issues.

\section{Reference}

Das, M.K and B.P, Choudhary. 2008. Plant Nomenclature and Biodiversity Conservation. Kalyani Publishers, India.180 pp.

FAO, 2010. Global Forest Resources Assessment 2010. WWW.fao.org.

William P. Cunningham and Mary Ann Cunningham, 2002. Principles of Environmental Science: Inquiry and Applications, 10th ed. Tata McGraw-Hill, India.418 pp.

\section{Article Information}

\section{Article history}

\begin{tabular}{|l|l|}
\hline Received & 21 November 2012 \\
\hline Received in revised form & 12 December 2012 \\
\hline Accepted & 18 December 2012 \\
\hline
\end{tabular}

